\title{
The Fate of Ammonium in Integrated Vertical-flow Constructed Wetlands Using Stable Isotope Technique
}

\author{
Yun Hu${ }^{1,2}$, Feng He ${ }^{1 *}$, Long Wang, ${ }^{1,2}$ Jian Sun ${ }^{1,2}$, \\ Tao Huang ${ }^{1,2}$, Zhenbin $\mathrm{Wu}^{1}$ \\ ${ }^{1}$ State Key Laboratory of Freshwater Ecology and Biotechnology, Institute of Hydrobiology, \\ Chinese Academy of Sciences, Wuhan 430072, China \\ ${ }^{2}$ University of Chinese Academy of Sciences, Beijing 100049, China
}

Received: 28 October 2015

Accepted: 19 January 2016

\begin{abstract}
The fate of ammonium $\left(\mathrm{NH}_{4}^{+}\right)$was investigated using the ${ }^{15} \mathrm{~N}$ tracer stable isotope technique in integrated vertical-flow constructed wetlands (IVCWs). Two types of IVCW systems were built: unplanted IVCWs (control) and planted IVCWs. The results showed that a high $\mathrm{NH}_{4}^{+}$removal efficiency $(95.4 \%)$ in the planted IVCWs. Plants not only removed $\mathrm{NH}_{4}{ }^{+}$by direct uptake (13.6 $\pm 0.7 \%$ ) but also improved the $\mathrm{NH}_{4}{ }^{+}$ removal capacity of IVCWs, compared with the control. Besides plant uptake, microbial conversion was the dominant mechanism of $\mathrm{NH}_{4}^{+}$removal in IVCWs, and a large proportion (75.2-85.6\%) of added $\mathrm{NH}_{4}{ }^{+}$may be permanently removed via anammox and nitrification-denitrification processes in IVCWs.
\end{abstract}

Keywords: ammonium, integrated vertical-flow constructed wetland, ${ }^{15} \mathrm{~N}$ tracer, plant uptake, stable isotope technique

\section{Introduction}

Ammonium $\left(\mathrm{NH}_{4}^{+}\right)$is one of the major nitrogen (N) contaminants in natural waters. It can cause serious environmental problems such as eutrophication and toxicity to aquatic organisms [1]. Owing to their low cost, easy operation, and high purification efficiency, constructed wetlands (CWs) have been given much attention for wastewater treatment [2]. However, not all $\mathrm{CW}$ types can achieve high $\mathrm{N}$ removal efficiency. Verticalflow constructed wetlands (VFCWs) are beneficial for nitrification, while horizontal subsurface-flow constructed

*e-mail: hefeng@ihb.ac.cn wetlands (HSSF-CWs) can only provide suitable conditions for denitrification [3]. In order to achieve higher $\mathrm{N}$ treatment efficacy, a hybrid system integrated vertical-flow constructed wetland (IVCW), consisting of a down-flow wetland unit and an up-flow one in series, was developed. Previous studies paid much attention to $\mathrm{N}$ removal efficiency in IVCWs [4-6], but information on quantitatively investigating $\mathrm{N}$ transformation forms and removal pathways has only rarely been reported.

The main $\mathrm{N}$ removal pathways in CWs are plant uptake, microbial conversion, volatilization, adsorption, and sedimentation [7]. When wastewater flows into the CWs, $\mathrm{NH}_{4}^{+}$can be absorbed by plants and substrate, oxidized to nitrite $\left(\mathrm{NO}_{2}^{-}\right)$, and further oxidized to nitrate $\left(\mathrm{NO}_{3}^{-}\right)$by nitrifying bacteria. Subsequently, the generated $\mathrm{NO}_{3}^{-}$can 
be reduced to $\mathrm{NO}_{2}^{-}$and converted into gas by denitrifying bacteria. Meanwhile, there is also a non-traditional microbial $\mathrm{N}$ removal pathway known as anammox, in which $\mathrm{NH}_{4}^{+}$is directly oxidized to $\mathrm{N}_{2}$ under anaerobic conditions [8]. However, the estimation of these $\mathrm{N}$ removal pathways in IVCWs was difficult because the aerobicanaerobic zone was complex and a variety of removal mechanisms were combined. A number of methods have been used to investigate $\mathrm{N}$ removal pathways, such as physicochemical measurements [9] and mass balance method [10]. Nevertheless, these methods had limitations and cannot be monitored by quantitative $\mathrm{N}$ transformation forms. In order to get accurate measurements of the proportions of $\mathrm{N}$ removal pathways in IVCWs, ${ }^{15} \mathrm{~N}$ tracer technique combined with mass balance method was used in this study.

The fate of $\mathrm{NH}_{4}^{+}$and its removal pathways in IVCWs were conducted using the stable isotope technique to reveal the black box of $\mathrm{N}$ forms interconversion. The study also provided information on the relative proportions of plant uptake, microbial conversion, substrate adsorption, and sedimentation.

\section{Materials and Methods}

\section{Design and Operation of the IVCWs}

Six IVCW systems, each with a down-flow Polyvinylchlorid $(\mathrm{PVC})$ column $($ diameter $=16 \mathrm{~cm}$, height $=100 \mathrm{~cm}$ ) and an up-flow column (diameter $=16 \mathrm{~cm}$, height $=100 \mathrm{~cm}$ ) with a working volume of $12 \mathrm{~L}$ were built near Donghu Lake in Wuhan, China. Gravel $(\varphi=5-8 \mathrm{~mm}$, porosity $=0.4$ ) was filled to a depth of $15 \mathrm{~cm}$, followed by an upper layer of $45 \mathrm{~cm}$ with washed river sand $(\varphi=0-4 \mathrm{~mm}$, porosity $=0.5)$ for the down-flow and upflow columns, respectively. Among the six systems, three unplanted ones were set as control group, and the downflow and up-flow columns of the other three were planted with equal size Canna indica L. (C. indica) (density $=50$ plants $/ \mathrm{m}^{2}$ ). The schematic representation of the IVCWs is shown in Fig. 1.

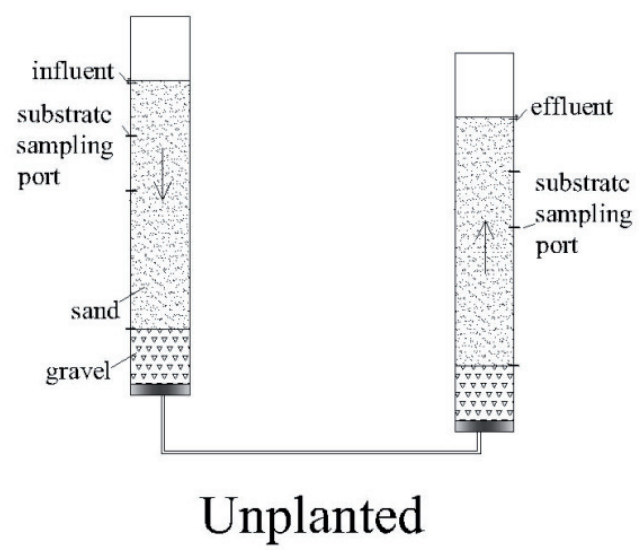

The IVCWs were fed with sewage wastewater for one month until the plant roots and microorganisms were well established. Then they were fed with simulated wastewater for two months. The influent simulated wastewater was prepared by tap water with dissolved ammonium chloride $\left(\mathrm{NH}_{4} \mathrm{Cl}\right)$, and the average concentration of total nitrogen (TN) was $15.4 \mathrm{mg} / \mathrm{L}, \mathrm{NH}_{4}^{+} 15.0 \mathrm{mg} / \mathrm{L}, \mathrm{NO}_{3}^{-} 0.4 \mathrm{mg} / \mathrm{L}$, and $\mathrm{NO}_{2}^{-}$not detected (Unpublished). Systems were operated in batch mode with a hydraulic retention time (HRT) of $6 \mathrm{~d}$ for each batch. Inflow water was added to the top of the down-flow column, and trickled through the up-flow column. The dissolved oxygen (DO) concentrations in unplanted and planted IVCWs along the direction of water flow were $0.16-1.47$ and $0.08-1.35 \mathrm{mg} / \mathrm{L}$, respectively. The experiments lasted from May to September, and the mean ( \pm standard deviation; s.d.), minimum, and maximum air temperatures were $29.5 \pm 3.8,18$, and $38^{\circ} \mathrm{C}$, respectively.

\section{${ }^{15} \mathrm{NH}_{4}^{+}$Trace Experiment}

In order to trace the fate of $\mathrm{NH}_{4}^{+},{ }^{15} \mathrm{~N}$-labelled $\mathrm{NH}_{4}^{+}$ wastewater was used as influent for one batch, which was synthesized with ${ }^{15} \mathrm{NH}_{4} \mathrm{Cl}\left({ }^{15} \mathrm{~N}\right.$ atom $\%=98$, SigmaAldrich) in tap water, and the characteristics of the influent were presented in Table 1. Samples of plant and substrate were taken to provide background values before applying ${ }^{15} \mathrm{~N}$-labelled $\mathrm{NH}_{4}^{+}$wastewater. The ${ }^{15} \mathrm{NH}_{4}^{+}$trace experiment lasted $6 \mathrm{~d}$.

\section{Sample Collection and Analysis}

\section{Water Samples}

Water samples $(200 \mathrm{~mL})$ were collected from the outlet of the IVCWs every day during trace experiment for analysis of $\mathrm{TN}, \mathrm{NH}_{4}^{+}, \mathrm{NO}_{3}^{-}$, and $\mathrm{NO}_{2}^{-}$. Each parameter was analyzed according to standard methods [11]. $\mathrm{pH}$ value was measured in situ with an Orion 5-Star portable conductivity multimeter (Thermo Fisher Scientific Company, USA). Chemical oxygen demand (COD) was measured using a spectrophotometer (DRB 200, Hach, USA).

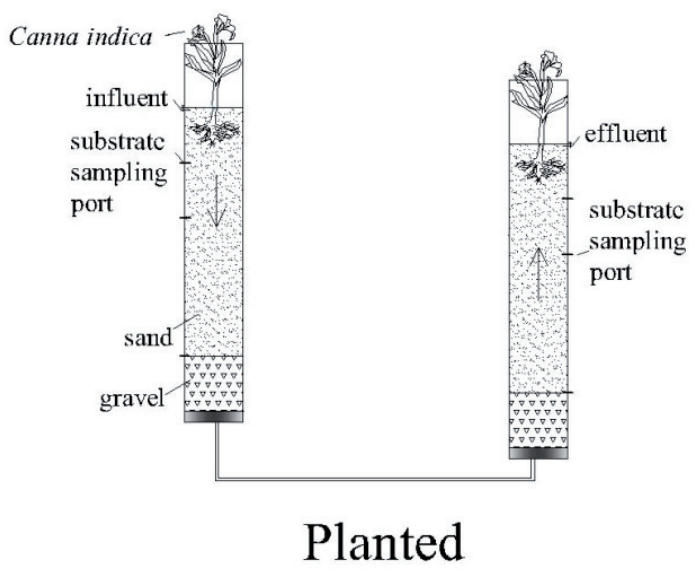

Fig. 1. Integrated vertical-flow constructed wetlands used in this study. 
Table 1. Characteristics of the influent of ${ }^{15} \mathrm{NH}_{4}^{+}$trace experiment.

\begin{tabular}{|c|c|c|c|c|c|}
\hline $\mathrm{pH}$ & $\mathrm{COD}$ & $\mathrm{NH}_{4}{ }^{+}-\mathrm{N}$ & $\mathrm{NO}_{3}{ }^{-} \mathrm{N}$ & $\mathrm{NO}_{2}^{-}-\mathrm{N}$ & $\mathrm{TN}$ \\
\hline & $\mathrm{mg} \cdot \mathrm{L}^{-1}$ & $\mathrm{mg} \cdot \mathrm{L}^{-1}$ & $\mathrm{mg} \cdot \mathrm{L}^{-1}$ & $\mathrm{mg} \cdot \mathrm{L}^{-1}$ & $\mathrm{mg} \cdot \mathrm{L}^{-1}$ \\
\hline $7.4 \pm 0.1$ & $15.0 \pm 1$ & $14.4 \pm 0.1$ & $0.4 \pm 0.0$ & $\mathrm{n} / \mathrm{d}$ & $14.8 \pm 0.1$ \\
\hline
\end{tabular}

Notes: a) Values are means ( \pm s.d., $n=3)$; b) n/d, not detected.

The diffusing method was used to measure the ${ }^{15} \mathrm{~N}$ content of $\mathrm{NH}_{4}^{+}$and $\mathrm{NO}_{\mathrm{x}}^{-}\left(\mathrm{NO}_{3}^{-}\right.$and $\left.\mathrm{NO}_{2}^{-}\right)$in water samples $[12,13] . \mathrm{NH}_{4}^{+}$and $\mathrm{NO}_{x}^{-}$were diffused in turn onto acidified GF/D glass fiber filter paper (Whatman) impregnated with $25 \mu \mathrm{L}$ of $2 \mathrm{M} \mathrm{H}_{2} \mathrm{SO}_{4}$ and enclosed within PTFE (Millipore LCWP02500) tape, which floated on the water sample. A known volume $(100 \mathrm{~mL})$ of sample was put in a $250 \mathrm{~mL}$ polyethylene bottle with the addition of $0.2 \mathrm{~g} \mathrm{MgO}$. Diffusion bottles were closed immediately and shaken for $6 \mathrm{~d}$ at $40^{\circ} \mathrm{C}$ on a horizontal shaker $(100$ $\mathrm{rpm})$. The PTFE tape was removed from the solution and diffusion bottles were left open for $24 \mathrm{~h}$ between the $\mathrm{NH}_{4}^{+}$ and $\mathrm{NO}_{\mathrm{x}}^{-}$diffusion period to remove the residual $\mathrm{NH}_{4}^{+}$. Then a new tape, $0.2 \mathrm{~g} \mathrm{MgO}$, and $0.4 \mathrm{~g}$ Devarda's alloy were added into the bottle and shaken for another $6 \mathrm{~d}$. After removal from the solution, the PTFE tapes were opened and the filters were dried. The filters were then packed in tin capsules and analyzed by an elemental analyzer (Carlo Erba NC 2500)-isotope ratio mass spectrometer (EAIRMS) (Finnigan MAT Delta-plus, Germany).

\section{Plant Samples}

The aboveground and belowground parts of $C$. indica were collected from the down-flow and up-flow columns of the IVCWs in the initial and at the end of the trace experiment. After collection, the samples were cleaned with distilled water, weighed wet, dried to constant weight at $50^{\circ} \mathrm{C}$, reweighed, and milled into a fine powder. Finally, the ${ }^{15} \mathrm{~N}$ content of aboveground and belowground parts of plants were determined on EA-IRMS.

\section{Substrate Samples}

To evaluate the changes in ${ }^{15} \mathrm{~N}$ content of the substrate, substrate samples were taken from the top $(10 \mathrm{~cm})$, middle $(20 \mathrm{~cm})$, and bottom $(45 \mathrm{~cm})$ sections of the down-flow and up-flow columns in the initial and at the end of the trace experiment, respectively. The samples were dried, ground, and weighed for analysis via EA-IRMS.

\section{Mass Balance Calculations}

Emission of ammonia is negligible due to the neutral $\mathrm{pH}$ in the influent [14]. The fate of ${ }^{15} \mathrm{NH}_{4}^{+}$in IVCWs could be attributed to four parts: plant uptake, substrate adsorption and sedimentation, microbial conversion, and untransformed. A ${ }^{15} \mathrm{~N}$ mass balance approach was used to calculate the mass and proportion of added ${ }^{15} \mathrm{NH}_{4}^{+}$ that were 1) plant uptake, 2) substrate adsorption and sedimentation, 3) untransformed ${ }^{15} \mathrm{NH}_{4}^{+}$, 4) ${ }^{15} \mathrm{NO}_{\mathrm{x}}^{-}$, and 5) unaccounted ${ }^{15} \mathrm{NH}_{4}^{+}$. The ${ }^{15} \mathrm{~N}$ mass was quantified by the following equation:

$$
\begin{gathered}
{ }^{15} N_{\text {mass }}=N_{\text {plant uptake }}+N_{\text {substrate adsorption and }} \\
\text { sedimentation } \\
+N_{\text {untransformed }}+N_{\text {microbial conversion }} \\
N_{\text {microbial conversion }}=N^{15} \mathrm{NOx}-^{-}+N_{\text {unaccounted }}
\end{gathered}
$$

\section{Data Analysis}

The amount of ${ }^{15} \mathrm{~N}$ in plants, substrate, and water was calculated by subtracting the amount of background ${ }^{15} \mathrm{~N}$. Independent samples t-tests were used to compare significant difference $(p<0.01)$ of the $\mathrm{N}$ removal efficiencies and the proportion of added ${ }^{15} \mathrm{NH}_{4}^{+}$in unplanted and planted IVCWs. The statistical analyses were performed by SPSS version 18.0 (IBM, USA).

\section{Results}

\section{N Removal Performance of the IVCWs}

The $\mathrm{N}$ removal performance of the unplanted and planted IVCWs was investigated. As shown in Fig. 2, during the trace experiment $\mathrm{TN}$ concentrations decreased from $14.8 \pm 0.1$ to $0.7 \pm 0.1 \mathrm{mg} / \mathrm{L}$, and $\mathrm{NH}_{4}^{+}$concentrations declined from $14.4 \pm 0.1$ to $0.7 \pm 0.1 \mathrm{mg} / \mathrm{L}$ in the planted IVCWs. The decline was significant for the first day and relatively constant over the remaining five days. The unplanted IVCWs exhibited a similar variation trend. Additionally, the planted IVCWs were maintained at a very low level of $\mathrm{NO}_{3}{ }^{-}$and $\mathrm{NO}_{2}{ }^{-}$concentrations compared with the unplanted ones. At the end of the experiment TN and $\mathrm{NH}_{4}^{+}$removal efficiencies can achieve $94.5 \pm 0.7 \%$ and $95.4 \pm 1.0 \%$ in the planted IVCWs, which were significantly higher $(p<0.01)$ than that in the unplanted ones. These results indicated the presence of plant-improved TN and $\mathrm{NH}_{4}^{+}$removal efficiencies in the IVCWs.

$$
\text { Fate of }{ }^{15} \mathrm{~N}-\mathrm{NH}_{4}^{+}
$$

To reveal the fate of ${ }^{15} \mathrm{~N}-\mathrm{NH}_{4}^{+}$in IVCWs, the same amount of ${ }^{15} \mathrm{NH}_{4}^{+}-\mathrm{N}(173.1 \pm 0.1 \mathrm{mg})$ was added into the unplanted and planted IVCWs. The mass and proportion of added ${ }^{15} \mathrm{NH}_{4}^{+}$were presented in Table 2. $13.6 \pm 0.7 \%$ of the added ${ }^{15} \mathrm{~N}$ was found in plants as a result of plant 
Table $2 .{ }^{15} \mathrm{NH}_{4}^{+}$mass balance summary .

\begin{tabular}{|c|c|c|c|c|}
\hline${ }^{15} \mathrm{~N}$ balance component & \multicolumn{2}{|c|}{ Mass of ${ }^{15} \mathrm{~N}(\mathrm{mg})$} & \multicolumn{2}{c|}{ Proportion of added ${ }^{15} \mathrm{NH}_{4}{ }^{+}(\%)$} \\
\hline 1. Amount ${ }^{15} \mathrm{NH}_{4}{ }^{+}$added & $\mathrm{W} 1$ & $\mathrm{~W} 2$ & $\mathrm{~W} 1$ & $\mathrm{~W} 2$ \\
\hline 2. Plant uptake & $173.1 \pm 0.1$ & $173.1 \pm 0.1$ & $100 \pm 0.1$ & $100 \pm 0.1$ \\
\hline 3. Substrate adsorption and sedimentation & $\mathrm{n} / \mathrm{a}^{\mathrm{b}}$ & $23.7 \pm 1.3$ & $\mathrm{n} / \mathrm{a}^{\mathrm{b}}$ & $13.6 \pm 0.7$ \\
\hline 4. Untransformed ${ }^{15} \mathrm{NH}_{4}{ }^{+}$ & $\mathrm{n} / \mathrm{d}^{\mathrm{b}}$ & $\mathrm{n} / \mathrm{d}^{\mathrm{b}}$ & $\mathrm{n} / \mathrm{d}^{\mathrm{b}}$ & $\mathrm{n} / \mathrm{d}^{\mathrm{b}}$ \\
\hline $5 .{ }^{15} \mathrm{NO}_{\mathrm{x}}{ }^{-}$ & $39.9 \pm 3.1$ & $7.0 \pm 1.5$ & $23.0 \pm 1.8$ & $4.1 \pm 0.9$ \\
\hline 6. Unaccounted ${ }^{15} \mathrm{NH}_{4}{ }^{+}[1 .-(2 .+3 .+4 .+5)]$. & $130.1 \pm 4.0$ & $142.2 \pm 2.7$ & $75.2 \pm 2.3$ & $0.1 \pm 0.0$ \\
\hline
\end{tabular}

Notes: a) Values are means ( \pm s.d., $n=3)$; b) n/d, not detected.

uptake. ${ }^{15} \mathrm{~N}$ in substrate adsorption and sedimentation were not detected in both unplanted and planted systems. $23.0 \pm 1.8 \%$ of the added ${ }^{15} \mathrm{NH}_{4}^{+}$was untransformed and remained in the unplanted systems at the end of the experiment. Compared with the unplanted systems, the planted IVCWs contained less untransformed ${ }^{15} \mathrm{NH}_{4}^{+}$. Additionally, the planted systems contained significantly lower ${ }^{15} \mathrm{NO}_{x}^{-}$than the unplanted one $(p<0.01)$. Specially, the proportion of transformed and unaccounted-for ${ }^{15} \mathrm{NH}_{4}^{+}$was $82.2 \pm 1.6 \%$ in the planted IVCWs, which was significantly higher $(p<0.01)$ than that in the unplanted ones. The result indicated that the microbial conversion in IVCWs was significantly affected by the existence of plants.

\section{Discussion}

${ }^{15} \mathrm{NH}_{4}^{+}$trace experiment results indicate that plant uptake accounted for only a modest proportion of $\mathrm{N}$ removal in IVCWs. This is in agreement with previous investigations. Matheson reported that plants assimilated $11-15 \% \mathrm{NH}_{4}^{+}$in wetland microcosms [15]. MaltaisLandrya found that the contribution of plant uptake to $\mathrm{N}$ removal was less than $20 \%$ in CW mesocosms [9]. Besides uptake by plants, the planted IVCWs permanently removed more ${ }^{15} \mathrm{NH}_{4}^{+}$than the unplanted ones. This phenomenon was similar to previous studies. Coban demonstrated that plants can enhance $\mathrm{NH}_{4}^{+}$removal efficiency in CWs [16]. Vacca illustrated that plants strongly influenced the microbial community in CWs [17]. Additionally, Gagnon
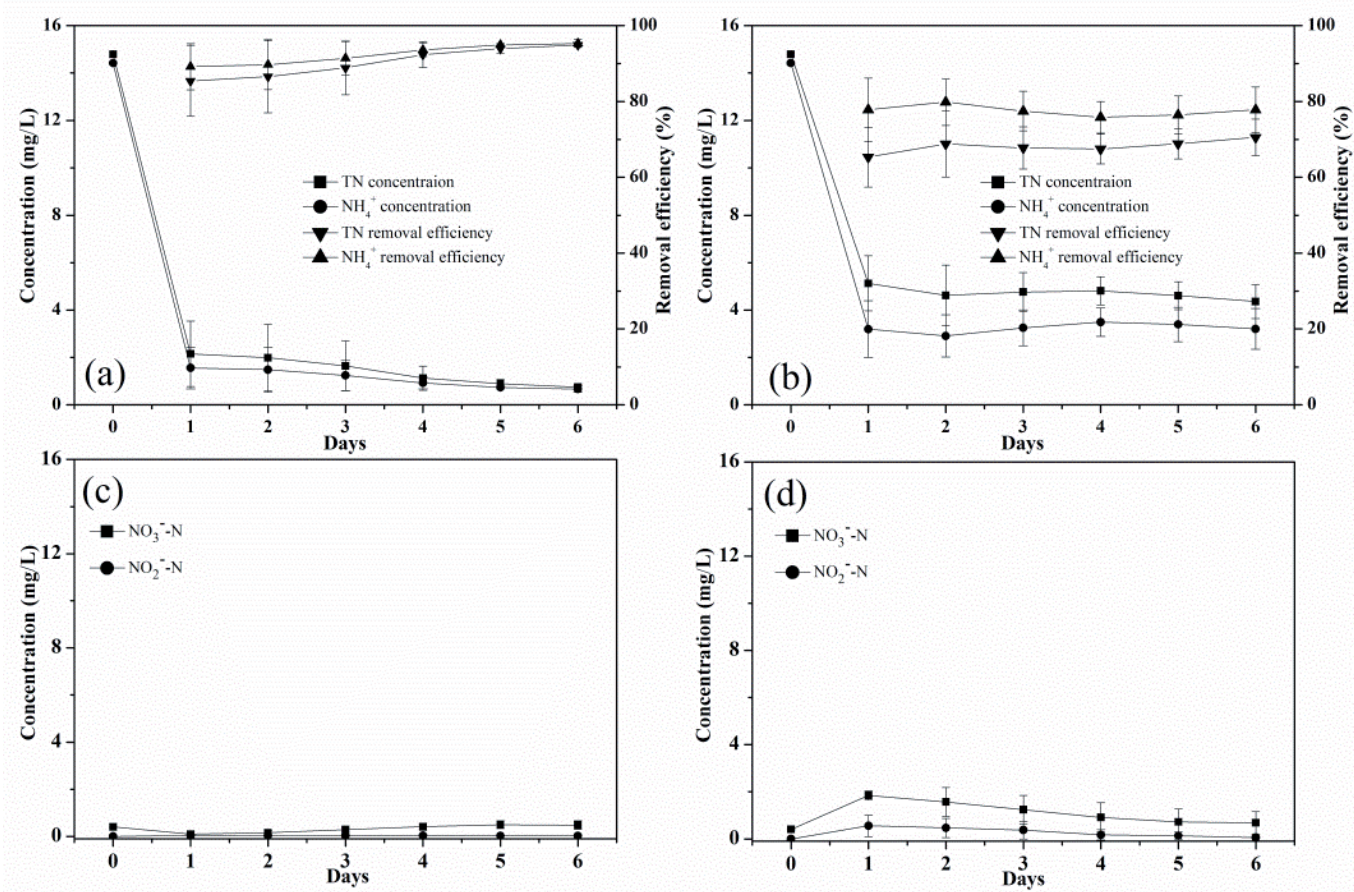

Fig. 2. N removal performance of the IVCWs. (a) and (c) Planted IVCWs; (b) and (d) Unplanted IVCWs. Values are means (Error bars indicate standard deviation, $\mathrm{n}=3$ ). 
revealed that the root oxygen release of plants influenced microbial diversity and activity [18]. It was supposed that plants could affect microbial conversion to improve $\mathrm{N}$ removal efficiency in IVCWs.

The substrate adsorption and sedimentation were not detected because $\mathrm{N}$ content in substrate is below the detection limits. Wen et al. demonstrated that the adsorption capacity of gravel and sand was very low, which can be negligible [19]. Additionally, Organic N particulate in the influent is difficult to be decomposed and could be removed through sedimentation in CWs [20]. In our study, the influent contained no organic $\mathrm{N}$ particulate. Given the above-considered points, the undetected substrate adsorption and sedimentation could be ignored.

A large proportion of the added ${ }^{15} \mathrm{NH}_{4}^{+}$was unaccounted for at the end of the experiment, assuming that the unaccounted fraction was transformed to undetected gas. The ratio was relatively higher than the comparable study $[15,21]$. It was shown by $\mathrm{Wu}$ et al. that the mean $\mathrm{NH}_{4}^{+}$removal efficiency was $16.5 \%$ in VFCWs [22]. Yalcuk and Ugurlu found that $\mathrm{NH}_{4}^{+}$removal efficiencies in VFCWs were 48.9-62.3\% [23]. Matheson and Sukias indicated that $36 \%$ of the added $\mathrm{NO}_{3}^{-}$was unaccounted for and transformed via denitrification to gas [24]. In the present study, 75.2-85.6\% of added ${ }^{15} \mathrm{NH}_{4}^{+}$ was unaccounted for. Thus it can be seen that there are other $\mathrm{N}$ removal pathways existing in IVCWs besides the conventional denitrification pathway. Possible reasons for the significant $\mathrm{N}$ removal in IVCWs probably rely on the combined effects of the influent and operational conditions. Influent $\mathrm{N}$ is mostly $\mathrm{NH}_{4}^{+}$and the $\mathrm{C} / \mathrm{N}$ ratio was only $1, \mathrm{DO}$ in the IVCWs ranged from 0.08 to $1.47 \mathrm{mg} / \mathrm{L}$, and the average air temperature was $29.5^{\circ} \mathrm{C}$. The suitable growth conditions for anammox were low DO concentration $(<2 \mathrm{mg} / \mathrm{L})$, low $\mathrm{NO}_{3}{ }^{-}$concentration $(<5 \mathrm{mg} / \mathrm{L}), \mathrm{NH}_{4}^{+}$-rich wastewater, appropriate temperature range $\left(20-43^{\circ} \mathrm{C}\right)$ and $\mathrm{pH} 6.7-8.3$ [25-27]. The phenomenon of high TN removal efficiency in CWs under low $\mathrm{C} / \mathrm{N}$ ratio and anaerobic conditions may be attributed to anammox [28, 29]. Therefore, the majority of transformed ${ }^{15} \mathrm{NH}_{4}^{+}$may be permanently removed through anammox and nitrification-denitrification processes to $\mathrm{N}_{2}, \mathrm{NO}$, and $\mathrm{N}_{2} \mathrm{O}$, and $\mathrm{N}$ gas emissions are usually dominated by $\mathrm{N}_{2}$ [30]. Future studies are likely to detect anammox bacteria in IVCWs.

\section{Conclusion}

In this study, ${ }^{15} \mathrm{~N}$ tracer technique combined with mass balance method was used to reveal $\mathrm{N}$ removal pathways. Integrated analysis confirmed that plant uptake and microbial conversion were the main mechanisms of $\mathrm{NH}_{4}^{+}$removal in IVCWs. The ${ }^{15} \mathrm{~N}$ mass balance approach showed that plants not only remove $\mathrm{N}$ by direct uptake $(13.6 \pm 0.7 \%)$, but also improve $\mathrm{N}$ removal efficiency in IVCW systems compared with unplanted systems. Moreover, a large proportion (75.2-85.6\%) of added $\mathrm{NH}_{4}^{+}$may be permanently removed through anammox and denitrification-nitrifiction processes to undetected gas. In future studies, we recommended further exploring the presence of anammox bacteria and investigating the relative $\mathrm{N}$ removal pathways in IVCWs.

\section{Acknowledgments}

This work was financially supported by the National Science and Technology Support Program of the $12^{\text {th }}$ Five-Year Plan, China (No. 2012BAJ21B03-04), the National Natural Science Foundation of China (No. 51178452), the Major Science and Technology Program for Water Pollution Control and Treatment of China of the $12^{\text {th }}$ Five-Year Plan (No. 2012ZX07101007-005), and the Hubei Province Science Foundation for Youths (No. 2014CFB282). We thank Profs. Yongyuan Zhang and Baoyuan Liu, Drs. Yafen Wang, Yi Zhang, Qiaohong Zhou, Biyun Liu, Enrong Xiao, Dong Xu, and Junmei $\mathrm{Wu}$, and Ms. Liping Zhang for experimental assistance and paper preparation (Institute of Hydrobiology, Chinese Academy of Sciences).

\section{References}

1. JELLALI S., WAHAB M.A., ANANE M., RIAHI K., JEDIDI N. Biosorption characteristics of ammonium from aqueous solution onto Posidonia oceancica (L.) fibers. Desalination. 270, 40, 2011.

2. ZHANG L.Y., XIA X.F., ZHAO Y., XI B.D., YAN Y.N., GUO X., XIONG Y., ZHAN J.H. The ammonium nitrogen oxidation process in horizontal subsurface flow constructed wetlands. Ecol. Eng. 37, 1614, 2011.

3. VYMAZAL J. Horizontal sub-surface flow and hybrid constructed wetlands systems for wastewater treatment. Ecol. Eng. 25 (5), 478, 2005.

4. TAO M., HE F., XU D., LI M., WU Z.B. How artificial aeration improved the sewage treatment of an integrated vertical-flow constructed wetland. Polish J. of Environ. Stud. 19 (1), 181, 2010.

5. CHANG J.J., WU S.Q., DAI Y.R., LIANG W., WU Z.B. Treatment performance of integrated vertical-flow constructed wetland plots for domestic wastewater. Ecol. Eng. 44, 152, 2012.

6. PENG L., HUA Y.M., CAI J.B., ZHAO J.W., ZHOU W.B. Effects of plants and temperature on nitrogen removal and microbiology in a pilot-scale integrated vertical-flow wetland treating primary domestic wastewater. Ecol. Eng. 64, 285, 2014.

7. VYMAZAL J. Removal of nutrients in various types of constructed wetlands. Sci. Total Environ. 380, 48, 2007.

8. MULDER A., VANDEGRAAF A.A., ROBERTSON L.A., KUENEN J.G. Anaerobic ammonium oxidation discovered in a denitrifying fluidized-bed reactor. FEMS Microbiol. Ecol. 16(3), 177, 1995.

9. MALTIS-LANDRYA G., MARANGER R., BRISSONA J., CHAZARENCB F. Nitrogen transformations and retention in planted and artificially aerated constructed wetlands. Water Res. 43, 535, 2009.

10. WU H.M., ZHANG J., WEI R., LIANG S. Nitrogen transformations and balance in constructed wetlands for slightly pollution river water treatment using different 
macrophytes. Environ. Sci. Pollut. Res. 20, 443, 2013.

11. STATE EPA OF CHINA (ED.). Monitoring and determination methods for water and wastewater, 4th ed. China Environmental Science Press, Beijing, 2002 [In Chinese].

12. STARK J.M., HART S.C. Diffusion technique for preparing salt solutions, kjeldahl digests and persulfate digests for nitrogen-15 analysis. Soil Sci. Soc. Am. J. 60 (6), 1846, 1996.

13. DIACONU C., BRION N., ELSKENNS M., BAEYENS W. Validation of a dynamic ammonium extraction technique for the determination of ${ }^{15} \mathrm{~N}$ at enriched abundances. Anal. Chim. Acta. 554, 113, 2005.

14. REDDY K.R., PATRICK W.H. Nitrogen transformations and loss in flooded soils and sediments. CRC Crit. Rev. Environ. Control. 13(4), 273, 1984.

15. MATHESON F.E., NGUYEN M.L., COPPER A.B., BURT T.P., BULL D.C. Fate of ${ }^{15} \mathrm{~N}$-nitrate in unplanted, planted and harvested riparian wetland soil microcosms. Ecol. Eng. 19, 249, 2002.

16. COBAN O., KUSCHK P., WELLS N.S., STRAUCH G., KNOELLER K. Microbial nitrogen transformation in constructed wetlands treating contaminated groundwater. Environ. Sci. Pollut. Res. 22 (17), 12829, 2015.

17. VACCA G., WAND H., NIKOLAUSZ M., KUSCHK P., KÄSTNER M. Effect of plants and filter materials on bacteria removal in pilot-scale constructed wetlands. Water Res. 39, 1373, 2015.

18. GAGNON V., CHAZARENC F., COMEAU Y., BRISSON $\mathrm{J}$. Influence of macrophyte species on microbial density and activity in constructed wetlands. Water Sci. Technol. 56 (3), 254, 2007.

19. WEN Y., XU C., LIU G., CHEN Y., ZHOU Q. Enhanced nitrogen removal reliability and efficiency in integrated constructed wetland microcosms using zeolite. Front. Environ. Sci. Eng. 6 (1), 140, 2012.

20. LEE C.G., FLETCHER T.D., SUN G.Z. Nitrogen removal in constructed wetland systems. Eng. Life Sci. 9 (1), 11, 2009.
21. MORAGHAN J.T. Loss and assimilation of ${ }^{15} \mathrm{~N}$-nitrate added to a North Dakota cattail marsh. Aquat. Bot. 46, 234, 1993.

22. WU Z.B., CHENG S.P., HE F., FU G.P., JIN J.M., CHEN H.R. Design and purification performance of vertical flow constructed wetland. Chinese J. of Appl. Ecol. 13, 715, 2002 [In Chinese].

23. YALCUK A., UGURLU A. Comparison of horizontal and vertical constructed wetland systems for landfill leachate treatment. Bioresour. Technol. 100, 2521, 2009.

24. MATHESON F.E., SUKIAS J.P. Nitrate removal processes in a constructed wetland treating drainage from dairy pasture. Ecol. Eng. 36, 1260, 2010.

25. JETTEN M.S.M., STROUS M., VAN DE PAS-SCHOONEN K.T., SCHALK J., VAN DONGEN U.G.J.M., VAN DE GRAAF A.A., LOGEMANN S., MUYZER G., VAN LOOSDRECHT M.C.M., KUENEN J.G. The anaerobic oxidation of ammonium. FEMS Microbiol. Rev. 22, 421, 1999.

26. JETTEN M.S.M., WAGNER M., FUWEST J., VAN LOOSDRECHT M., KUENEN G., STROUS M. Microbiology and application of the anaerobic ammonium oxidation ('anammox') process. Curr. Opin. Biotech. 12 (3), 283, 2001.

27. ZHU G.B., JETTEN M.S.M., KUSCHK P., ETTWIG K.F., YIN C.Q. Potential roles of anaerobic ammonium and methane oxidation in the nitrogen cycle of wetland ecosystems. Appl. Microbiol. Biotechnol. 86 (4), 1043, 2010.

28. TAO W.D., WANG J. Effects of vegetation, limestone and aeration on nitritation, anammox and denitrification in wetland treatment systems. Ecol. Eng. 35, 836, 2009.

29. WANG L., LI T. Anaerobic ammonium oxidation in constructed wetlands with bio-contact oxidation as pretreatment. Ecol. Eng. 37, 1225, 2011.

30. REDDY K.R., DELAUNE R.D. Biogeochemistry of wetlands: Science and Applications, CRC Press, 2008. 